\section{An unrecognized disease in routine clinical practice: the Heyde's syndrome}

\author{
Beatrice Casadei, Valentina Grasso, \\ Giulio Cariani, Bahjat Barakat, \\ Raffaele Pezzilli
}

Department of Digestive Diseases and Internal Medicine, S. Orsola-Malpighi University Hospital, Bologna, Italy

\section{Abstract}

Heyde's syndrome (HS) is a triade constituted by aortic stenosis, gastrointestinal angiodysplasia and deficiency of high-molecular-weight von Willebrand factor multimers. Until now few cases of HS has been reported and we believe of interest to add a new patient having this disorder. We report a case of HS in an 86-year-old female patient admitted for the second episode of melena in the last 4 months. A colonoscopy revealed a bleeding due to angiodysplasia in the ascending colon and an endoscopic argon laser photocoagulation of the colonic angiodysplasia was successfully carried out. Physicians should be aware of the possibilities of acquired von Willebrand disease and gastrointestinal bleeding from angiodysplasia in patients with aortic valve stenosis because a right diagnosis affects the management of these patients, especially in emergency situations.

\section{Introduction}

The association between calcific aorticvalve stenosis and gastrointestinal (GI) bleeding was firstly described by Edward Heyde in the 1958 who reported ten elderly patients with calcific aortic stenosis and massive GI bleeding of obscure origin. ${ }^{1}$ In 1986 submucosal angiodysplasia was identified as a possible source of GI bleeding in patients with aorticvalve stenosis. ${ }^{2}$ One year later, King et al. reported the cessation of GI bleeding after aortic-valve replacement and confirmed the association between degenerative aortic-valve stenosis and GI bleeding due to angiodysplasia. ${ }^{3}$ A key study in understanding of this disease was carried out by Warkentin et al. who suggested that HS was a form of type $2 \mathrm{~A}$ von Willebrand disease (vWD), an acquired syndrome characterized by a deficiency of highmolecular-weight von Willebrand factor multimers (vWf). ${ }^{4}$ VWf is a multimeric glycoprotein produced in endothelium and megacaryocites, playing a role in primary hemostasis because it permits the adhesion of platelets to the vascu- lar subendothelium. The high molecular weight multimers are important for maintaining hemostasis during high shear stress, a condition that is found in patients with angiodysplastyc malformations. ${ }^{4}$ Thus, the HS is a triade constituted by aortic-valve stenosis, GI angiodysplasia and deficiency of highmolecular-weight von Willebrand factor multimers. Until now few cases of Heyde's syndrome has been reported and we believe of interest to add a new case of patient having this syndrome.

\section{Case Report}

An 86-year-old female patient was hospitalized for the second episode of melena within 4 months. The patient had a history of sclerodermia with calcinosis, Raynaud's syndrome, esophageal dysmotility, sclerodactyly and telangiectasia (CREST) syndrome, hypothyroidism, chronic obstructive pulmonary disease, arterial hypertension and aortic-valve stenosis. Cardiac auscultation revealed a grade III/IV systolic murmur at the second right intercostal space radiating to the neck and digital rectal examination showed melena. Laboratory examination revealed a hypocromic microcytic anemia with haemoglobin concentrations of $7.2 \mathrm{~g} / \mathrm{dL}$, MCV $72 \mathrm{fL}$ and MCH 22.5 pg; the platelet count was normal whereas an iron deficiency was detected (concentration of iron in blood serum was $30 \mathrm{mg} / \mathrm{dL}$ ). A decrease of large molecular weight multimers of von Willebrand factor was finally detected. The transthoracic echocardiogram showed a severe aortic stenosis due to degenerative valve calcification with a mean transvalvular gradient of $41 \mathrm{mmHg}$ and a valvular area of $0.9 \mathrm{~cm}^{2}$. The endoscopic study of colon revealed a bleeding due to angiodysplasia in the ascending colon (Figure 1). The selective angiography of mesenteric arteries did not show an active bleeding. Other sites of bleeding in the digestive tract were also excluded by capsule endoscopy. The patient was supported with blood transfusions and iron supplement was also given intravenously. An endoscopic argon laser photocoagulation of the colonic angiodysplasia was successfully carried out (Figure 2).

Considering her age and comorbidities determining a significant surgical and anaesthesiological risk, surgical valve replacement was not performed. After six month of followup, the patient remained in good clinical conditions and no further GI bleeding occurred.

\section{Discussion}

The association between calcific aortic-
Correspondence: Raffaele Pezzilli, Department of Digestive Diseases and Internal Medicine, S. Orsola-Malpighi University Hospital, via Massarenti 9, 40138 Bologna, Italy.

Tel. +39.051.6364148 - Fax: +39.051.6364148.

E-mail: raffaele.pezzilli@aosp.bo.it

Key words: aortic stenosis, angiodysplasia, gastrointestinal bleeding, Heyde's syndrome, von Willebrand factor.

Contributions: the authors contributed equally.

Conflict of interests: the authors declare no potential conflict of interests.

Received for publication: 9 May 2013.

Revision received: 28 June 2013.

Accepted for publication: 5 September 2013.

This work is licensed under a Creative Commons Attribution 3.0 License (by-nc 3.0).

@C Copyright B. Casadei et al., 2014

Licensee PAGEPress, Italy

Emergency Care Journal 2014; 10:1649

doi:10.4081/ecj.2014.1649

valve stenosis and GI bleeding due to angiodysplasia has been confirmed by various studies and the prevalence varies among the studies so far published. ${ }^{2,5}$ As in this reported case, both these disorders appear in elderly patients and are related to the degenerative process of aging. ${ }^{6}$ As shown in Table 1, there is no gender preference, the age of patients having this syndrome is advanced (median 70 years) and all bowel segments may be involved by the angiodysplasia. The risk of mucosal bleeding is caused by the acquired type $2 \mathrm{~A}$ von Willebrand syndrome that is a consequence of a high shear stress presented in narrowed valve. ${ }^{41}$ During passing through stenotic aortic valves, the coiled von Willebrand multimer, which normally circulates in plasma, is converted into an elongated highly asymmetric protein exposing the A2 domain. The metalloproteinase ADAMTS- 13 binds the A2 domain and causes the proteolysis of the high-molecular-weight multimers into smaller multimers that are less hemostatically competent. ${ }^{42}$ In most cases the loss of high-molecular-weight multimers is associated with abnormalities in platelet adhesion and aggregation in vitro. ${ }^{43}$ Vincentelli et al. reported that the $21 \%$ of 42 patients with severe aortic-valve stenosis had a history of mucosal bleeding with platelet function abnormalities and reduction of highmolecular-weight vWf multimers. ${ }^{44}$ These data showed that the loss of largest multimers was inversely correlated with the transvalvular aortic gradient and the valve replacement halted the depletion of these multimers. In addition, von Willebrand factor is essential for 
Table 1. Clinical characteristics of patients having Heyde's syndrome in case reports and two retrospective studies.

\begin{tabular}{|c|c|c|c|c|c|c|}
\hline Case reports & $\begin{array}{l}\text { Cases } \\
\text { (n.) }\end{array}$ & Gender & $\begin{array}{l}\text { Age at } \\
\text { diagnosis }\end{array}$ & $\begin{array}{c}\text { Site } \\
\text { angiodysplasia }\end{array}$ & $\begin{array}{l}\text { Bleeding } \\
\text { recurrence }\end{array}$ & Treatment \\
\hline Galloway et al. ${ }^{7}$ & 3 & $3 \mathrm{~F}$ & $53,71,70$ & Ascending colon & & Blood transfusions, right colectomy \\
\hline Gelfand et $a l^{8}$ & 5 & $2 \mathrm{M}, 3 \mathrm{~F}$ & 65 & $\begin{array}{l}4 \text { ascending colon, } \\
1 \text { small bowel }\end{array}$ & & $\begin{array}{c}5 \text { Blood transfusions, } 4 \text { right colectomy, } \\
1 \text { resection of jejunum }\end{array}$ \\
\hline Boyle et al. ${ }^{9}$ & 1 & $1 \mathrm{~F}$ & 64 & Not identified & & Aortic valve replacement \\
\hline Cappell and Lebwohl ${ }^{10}$ & 2 & $2 \mathrm{~F}$ & 66,69 & $\begin{array}{l}1 \text { gastroduodenal, } \\
1 \text { stomach, colon }\end{array}$ & & $\begin{array}{l}\text { Aortic valve replacement, } \\
\text { blood transfusion, iron supplementation }\end{array}$ \\
\hline Baciewicz and Davis ${ }^{11}$ & 1 & $1 \mathrm{M}$ & 48 & Descending colon & Yes & Colectomy with ileoproctostomy \\
\hline Casson and McKenzie $^{12}$ & 1 & $1 \mathrm{~F}$ & 68 & Stomach & & Endoscopic sclerosis \\
\hline Apostolakis et al..$^{13}$ & 2 & $1 \mathrm{M}, 1 \mathrm{~F}$ & 67,68 & 2 Colon & & Aortic valve replacement, blood transfusion \\
\hline Kraft and Hahn ${ }^{14}$ & 4 & $3 \mathrm{M}, 1 \mathrm{~F}$ & $67,87,74,73$ & $\begin{array}{l}3 \text { small bowel } \\
1 \text { colon }\end{array}$ & & Resection, blood transfusion \\
\hline Natowitz et al..$^{15}$ & 2 & $1 \mathrm{M}, 1 \mathrm{~F}$ & 72,74 & 2 small bowel & & Replacement of the aortic valve \\
\hline Knobloch et al. ${ }^{16}$ & 2 & $1 \mathrm{M}, 1 \mathrm{~F}$ & 61,75 & $\begin{array}{l}1 \text { not identified } \\
1 \text { small bowel }\end{array}$ & & Aortic valve replacement, blood transfusion \\
\hline Granel et al. ${ }^{17}$ & 1 & $1 \mathrm{M}$ & 61 & Small bowel & & Aortic valve replacement, blood transfusion \\
\hline Luckraz et al. ${ }^{18}$ & 1 & $1 \mathrm{~F}$ & 80 & Small bowel & Yes & $\begin{array}{c}\text { Aortic valve replacement, } \\
\text { endoscopic argon plasma coagulation }\end{array}$ \\
\hline Lee et al..$^{19}$ & 1 & $1 \mathrm{~F}$ & 68 & Colon & Yes & Hemicolectomy, argon plasma coagulation \\
\hline Pennacchietti and Capone ${ }^{20}$ & 1 & $1 \mathrm{~F}$ & 72 & Not identified & & Medical treatment \\
\hline Corrêa et al.. ${ }^{21}$ & 1 & 1 & 89 & Small bowel & & Medical treatment \\
\hline Giovannini et al. ${ }^{22}$ & 1 & $1 \mathrm{M}$ & 70 & Small bowel & Yes Righ & ght hemicolectomy and resection of terminal ileum \\
\hline Ogano et al..$^{23}$ & 1 & $1 \mathrm{M}$ & 64 & Colon & & Colectomy \\
\hline De Palma et al. ${ }^{24}$ & 1 & $1 \mathrm{M}$ & 58 & Small bowel & & Octreotide $20 \mathrm{mg}$, at monthly interval \\
\hline Morishima et $a l^{25}$ & 1 & $1 \mathrm{~F}$ & 78 & Small bowel & & $\begin{array}{l}\text { Aortic valve replacement, supplementation } \\
\text { of von Willebrand factor and factor VIII }\end{array}$ \\
\hline Henne et al..$^{26}$ & 1 & $1 \mathrm{M}$ & 60 & Stomach & Yes & Endoscopic argon plasma coagulation \\
\hline Schmid et al..$^{27}$ & 1 & $1 \mathrm{M}$ & 79 & Colon & & Medical treatment \\
\hline Hokama et al. ${ }^{28}$ & 1 & $1 \mathrm{~F}$ & 90 & Ascending colon & & Hemoclipping \\
\hline Hui et al. ${ }^{29}$ & 1 & $1 \mathrm{~F}$ & 68 & Small bowel & & $\begin{array}{l}\text { Blood transfusion, iron supplements, } \\
\text { endoscopic treatment }\end{array}$ \\
\hline Rahhal and Chamberlain ${ }^{30}$ & 1 & $1 \mathrm{~F}$ & 64 & Cecum & & Endoscopic laser coagulation \\
\hline Gandhi et al..$^{31}$ & 1 & $1 \mathrm{~F}$ & 82 & Ascending colon & & Medical treatment \\
\hline Takahashi et al. ${ }^{32}$ & 1 & $1 \mathrm{~F}$ & 82 & Colon & & $\begin{array}{l}\text { Endoscopic clipping before the successful aortic } \\
\text { valve replacement }\end{array}$ \\
\hline Vaz et al. ${ }^{33}$ & 1 & $1 \mathrm{M}$ & 69 & Stomach & & $\begin{array}{l}\text { Blood transfusion, iron supplements, } \\
\text { endoscopic argon, laser photocoagulation, } \\
\text { valve replacement }\end{array}$ \\
\hline García-Martín et al. ${ }^{34}$ & 1 & $1 \mathrm{~F}$ & 89 & Small bowel & & Intestinal resection \\
\hline Figuinha et al. ${ }^{35}$ & 1 & $1 \mathrm{M}$ & 76 & Ascending colon & & Medical treatment \\
\hline Abi-Akar et al. ${ }^{36}$ & 1 & $1 \mathrm{M}$ & 68 & Duodenum and colon & Yes & Blood transfusions, endoscopic treatment \\
\hline Gül et al. ${ }^{37}$ & 1 & $1 \mathrm{~F}$ & 75 & ecum and distal ileum & Yes & $\begin{array}{l}\text { Valve replacement, endoscopic argon plasma } \\
\text { coagulation, blood transfusion }\end{array}$ \\
\hline Godino et al. ${ }^{38}$ & 1 & $1 \mathrm{~F}$ & 83 & Duodenum & Yes & Endoscopic argon plasma coagulation \\
\hline Present case & 1 & $1 \mathrm{~F}$ & 86 & Ascending colon & & $\begin{array}{l}\text { Blood transfusion, iron supplements, } \\
\text { endoscopic laser coagulation }\end{array}$ \\
\hline Overall & 46 & $\begin{array}{l}18 \mathrm{M}(39.1 \%) \\
28 \mathrm{~F}(60.9 \%)\end{array}$ & $\begin{array}{l}\text { Median age } \\
71 \text { yrs }\end{array}$ & & $10(21.7 \%)$ & \\
\hline \multicolumn{7}{|l|}{ Retrospective studies } \\
\hline Thompson et al. ${ }^{39}$ & 57 & $\begin{array}{c}39 \mathrm{M}(68.4 \%) \\
18 \mathrm{~F}(31.6 \%)\end{array}$ & $\begin{array}{l}\text { Median age } \\
\quad 75 \text { yrs }\end{array}$ & $\begin{array}{l}\text { Duodenum- } \\
\text { ascending colon }\end{array}$ & $12(21.1 \%)$ & Aortic valve replacement \\
\hline Godino et al..$^{40}$ & 7 & NR & Mean age $78 \pm 10$ yrs & NR & $2(28.6 \%)$ & NR \\
\hline
\end{tabular}

M, male; F, female; NR, not reported. 
the role of platelets in maintaining vascular integrity independent of their essential function in hemostasis; in fact, in young patients with von Willebrand's disease capillary dilatation, tortuosity, and blood extravasation are observed on nail-bed capillaroscopy and angiodysplasia may be a consequence of von Willebrand factor alteration. ${ }^{45}$ As shown in Table 1, various treatments have been proposed for the gastrointestinal bleeding due to angiodysplasia varying from conservative medical treatment to surgery.

The main disagreements regarding the $\mathrm{HS}$ are not on the association between aortic stenosis and angiodysplasia, but on the pathogenesis of Heyde's syndrome, ranging from vWf deficiency and age-related degeneration to mucosal ischemia and cholesterol embolization. ${ }^{46}$ However, after a revision of literature data, it has been claimed that HS exists and this assumption is based on two factors: the gastrointestinal bleeding caused by angiodysplasia ceases in the major part of patients after valve replacement even if angiodysplasia

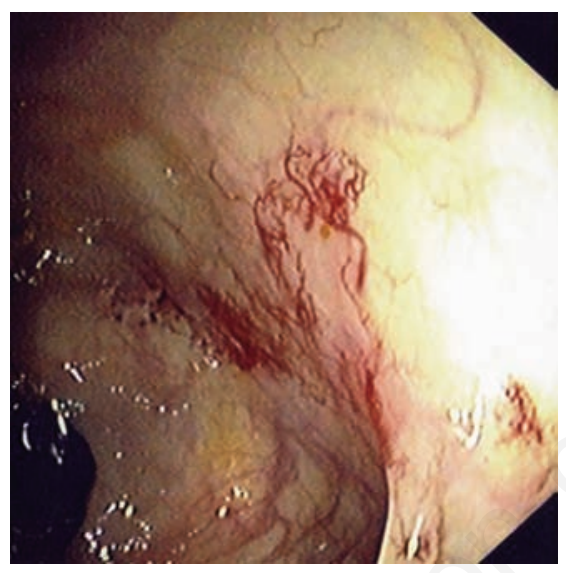

Figure 1. Colonoscopy showing bleeding due to angiodysplasia in the ascending colon.

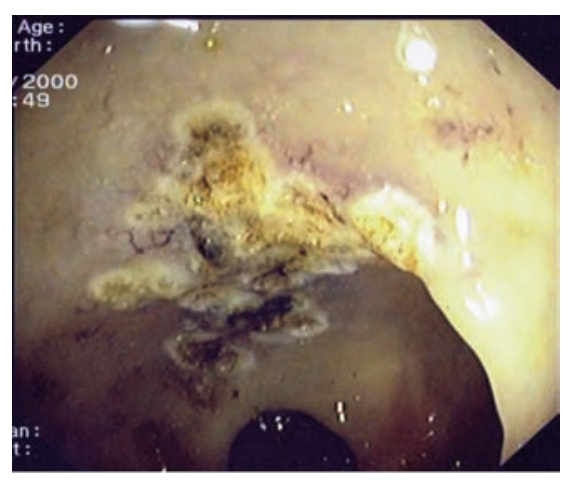

Figure 2. Colonoscopy showing the results of argon laser photocoagulation of the angiodysplasia. remains and the cause of the association between aortic stenosis and bleeding from angiodysplasia is still uncertain, but impaired aggregability of thrombocytes does not seem to be a simple explanation. ${ }^{47}$

Nowadays endoscopic laser photocoagulation seems to be the choice when the intestinal angiodysplasia can be reached by endoscopy. Rebleeding is reported in one-third of cases. ${ }^{39}$ In patients with severe symptomatic aorticvalve stenosis, the valve replacement is indicated as a gold standard for the definitive resolution of GI bleeding. ${ }^{48}$

\section{Conclusions}

Hyede's syndrome is a disorder in which aortic-valve stenosis can be complicated by GI bleeding due to angiodysplasia and type $2 \mathrm{~A}$ von Willebrand disease; physicians should be aware of the possibilities of acquired von Willebrand disease and gastrointestinal bleeding from angiodysplasia in patients with aortic valve stenosis because a right diagnosis affects the management of patients with gastrointestinal bleeding and aortic-valve stenosis. Of course, we must be aware that digestive endoscopy should be carried out after causes of bleeding eventually associated with Heyde's syndrome have been ruled out such as epistaxis, ecchymoses, menorrhagia or metrorrhagia, hematuria, or bleeding induced by dental extraction. ${ }^{4}$

\section{References}

1. Heyde EC. Gastrointestinal bleeding in aortic stenosis. New Engl J Med 1958;259:196.

2. Greenstein RJ, McElhinney AJ, Reuben D, Greenstein AJ. Colonic vascular ectasias and aortic stenosis: coincidence or casual relationship? Am J Surg 1986;151:347-51.

3. King RM, Pluth JR, Giuliani ER. The association of unexplained gastrointestinal bleeding with calcific aortic stenosis. Ann Thorac Surg 1987;44:514-6.

4. Warkentin TE, Moore JC, Morgan DG. Aortic stenosis and bleeding gastrointestinal angiodysplasia: is acquired von Willebrand's disease the link? Lancet 1992;340:35-7.

5. Pate GE, Mulligan A. An epidemiological study of Heyde syndrome: an association between aortic stenosis and gastrointestinal bleeding. J Heart Valve Dis 2004;13: 713-6.

6. Sucker C. The Heyde syndrome: proposal for unifying concept explaining the association of aortic valve stenosis, gastroin- testinal angiodysplasia and bleeding. Int $\mathrm{J}$ Cardiol 2007;115:77-8.

7. Galloway SJ, Casarella WJ, Shimkin PM. Vascular malformations of the right colon as a cause of bleeding in patients with aortic stenosis. Radiology 1974;113:11-5.

8. Gelfand ML, Cohen T, Ackert JJ, et al. Gastrointestinal bleeding in aortic stenosis. Am J Gastroenterol 1979;71:30-8.

9. Boyle JM, Rowen HE Jr, Saito H, et al. Severe aortic stenosis in a patient with recurrent gastrointestinal bleeding: replacement of the aortic valve with a porcine xenograft. Am J Gastroenterol 1981;75:135-9.

10. Cappell MS, Lebwohl 0. Cessation of recurrent bleeding from gastrointestinal angiodysplasias after aortic valve replacement. Ann Intern Med 1986;105:54-7.

11. Baciewicz FA Jr, Davis JT. Heyde's syndrome: failure of a mechanical prosthesis and the possibility of a coagulation defect. Ann Thorac Surg 1987;44:554-5.

12. Casson AG, McKenzie NN. Heyde's syndrome. Chest 1988;94:891-2.

13. Apostolakis E, Doering C, Kantartzis M, et al. Calcific aortic-valve stenosis and angiodysplasia of the colon: Heyde's syndrome. Report of two cases. Thorac Cardiov Surg 1990:38:374-6.

14. Kraft P, Hahn EG. Heyde syndrome: association between calcifying aortic valve stenosis and gastrointestinal hemorrhage of uncertain origin. Med Klin (Munich) 1993;88:67-71.

15. Natowitz L, Defraigne J0, Limet R. Association of aortic stenosis and gastrointestinal bleeding (Heyde's syndrome). Report of two cases. Acta Chir Belg 1993;93:31-3.

16. Knobloch W, Hauser E, Niehues R, et al. Calcifying aortic valve stenosis and occult gastrointestinal hemorrhage (Heyde syndrome): description of 2 cases. Z Kardiol 1999;88:448-53.

17. Granel B, Serratrice J, Bernit E, et al. Heyde syndrome. Presse Med 2002;31: 1451-3.

18. Luckraz H, Hashim S, Ashraf S. Aortic stenosis and angiodysplasia in the elderly: common things occur commonly? Interact Cardiovasc Thorac Surg 2003;2:526-8.

19. Lee TY, Han SY, Moon SH, et al. A case of Heyde's syndrome with abnormal von Willebrand factor. Korean J Gastroenterol 2004;43:133-6.

20. Pennacchietti L, Capone PL. [Severe aortic stenosis in the elderly and cryptogenic intestinal bleeding (Heyde syndrome): a case report]. [Article in Italian]. Ital Heart J Suppl 2004;5:741-5.

21. Corrêa PL, Felix RC, Azevedo JC, et al. Gastrointestinal bleeding diagnosed by red blood cell scintigraphy in a patient with 
aortic stenosis: a case of Heyde syndrome. Clin Nucl Med 2005;30:231-5.

22. Giovannini I, Chiarla C, Murazio M, et al. An extreme case of Heyde syndrome. Digest Surg 2006;23:387-8.

23. Ogano M, Iwasaki YK, Takano $\mathrm{H}$, et al. Successful colectomy for the treatment of repetitive bleeding from colonic angiodysplasia in a patient with Heyde syndrome. Intern Med J 2006;45:355-8.

24. De Palma GD, Salvatori F, Masone S, et al. Acute gastrointestinal bleeding following aortic valve replacement in a patient with Heyde's sindrome. Case report. Minerva Gastroenterol Dietol 2007;53:291-3.

25. Morishima A, Marui A, Shimamoto T, et al. Successful aortic valve replacement for Heyde syndrome with confirmed hematologic recovery. Ann Thorac Surg 2007;83:287-8.

26. Henne S, Denzer U, Seitz U, Göttsche J, Soehendra N, Lohse A. Recurrent gastrointestinal bleeding and aortic valve stenosis (Heyde syndrome): need for valve replacement? Z Gastroenterol 2007;45:245-9.

27. Schmid W, Steindl-Munda P, Madl C, et al. Estimation of platelet function under high shear conditions to assist a rapid diagnosis of Heyde Syndrome. Platelets 2008;19: 636-40.

28. Hokama A, Kishimoto K, Higashiarakawa $\mathrm{M}$, et al. Heyde syndrome: a common but less recognized complex of aortic stenosis and bleeding intestinal angiodysplasia. South Med J 2009;102:1279.

29. Hui YT, Lam WM, Fong NM, et al. Heyde's syndrome: diagnosis and management by the novel single-balloon enteroscopy. Hong Kong Med J 2009;15:301-3.
30. Rahhal F, Chamberlain S. Education and imaging. Gastrointestinal: Heyde's syndrome. J Gastroen Hepatol 2009;24:1150.

31. Gandhi V, Philip S, Nagral S. Heyde syndrome. Trop Gastroenterol 2010;31:120-1.

32. Takahashi N, Tanabe K, Yoshitomi H, et al. Successful endoscopic clipping for bleeding from colonic angiodysplasia in a case of Heyde syndrome. Med Sci Monitor 2010;16:107-9.

33. Vaz A, Correia A, Martins B, et al. Heyde syndrome: the link between aortic stenosis and gastrointestinal bleeding. Rev Port Cardiol 2010;29:309-14.

34. García-Martín A, Moreno A, Moro C. Heyde's syndrome. Rev Esp Cardiol 2011;64:75-7.

35. Figuinha FC, Spina GS, Tarasoutchi F. Heyde's syndrome: case report and literature review. Arq Bras Cardiol 2011;96:e425.

36. Abi-Akar R, El-Rassi I, Karam N, et al. Treatment of Heyde's syndrome by aortic valve replacement. Curr Cardiol Rev 2011;7:47-9.

37. Gül M, Sürgit Ö, Özal E, et al. Treatment of aortic valve stenosis and gastrointestinal bleeding by transcatheter aortic valve implantation in Heyde syndrome. Anadolu Kardiyol Derg 2012;12:691-3.

38. Godino C, Pavon AG, Mangieri A, Margonato A. Aortic valvuloplasty as bridging for TAVI in high-risk patients with Heyde's syndrome: a case report. Case Rep Med 2012;2012:946764.

39. Thompson JL 3rd, Schaff HV, Dearani JA, et al. Risk of recurrent gastrointestinal bleeding after aortic valve replacement in patients with Heyde syndrome. J Thorac
Cardiov Sur 2012;144:112-6.

40. Godino C, Lauretta L, Pavon AG, et al. Heyde's syndrome incidence and outcome in patients undergoing transcatheter aortic valve implantation. J Am Coll Cardiol 2013;61:687-9.

41. Tsai HM, Sussman II, Nagel RL. Shear stress enhances the proteolysis of von Willebrand factor in normal plasma. Blood 1994;83:2171-9.

42. Crawley JT, de Groot R, Xiang Y, et al. Unraveling the scissile bond: how ADAMTS 13 recognize and cleaves von Willebrand factor. Blood 2011;118:3212-21.

43. Panzer S, Badr Eslam R, Schneller A, et al. Loss of high-molecular-weight von Willebrand factor multimers mainly affects platelet aggregation in patients with aortic stenosis. Thromb Haemostasis 2010; 103:408-14.

44. Vincentelli A, Susen S, Le Tourneau T, et al. Acquired von Willebrand syndrome in aortic stenosis. New Engl J Med 2003;349: 343-9.

45. Loscalzo J. From clinical observation to mechanism. Heyde's syndrome. New Engl J Med 2012;367:1954-6.

46. Islam S, Cevik C, Islam E, et al. Heyde's syndrome: a critical review of the literature. J Heart Valve Dis 2011;20:366-75.

47. Larsen NH. Heyde syndrome. Ugeskrift Laeger 1997;159:4628-30.

48. Anderson RP, McGrath K, Street A. Reversal of aortic stenosis, bleeding gastrointestinal angiodysplasia and von Willebrand syndrome by aortic valve replacement. Lancet 1996;347:689-90. 